\title{
Phytochemical characterization of essential oil from Ocimum selloi*
}

\author{
LILIA A.S. MORAES ${ }^{1}$, ROSELAINE FACANALI ${ }^{2}$, MARCIA ORTIZ M. MARQUES ${ }^{2}$, \\ LIN CHAU MING ${ }^{1}$ and M. ANGELA A. MEIRELES ${ }^{3}$ \\ ${ }^{1}$ Faculdade de Ciências Agronômicas, Universidade Estadual Paulista, Cx. Postal 237 \\ 18603-970 Botucatu, SP, Brazil \\ ${ }^{2}$ Centro de Genética, Biologia Molecular e Fitoquímica, Instituto Agronômico, Cx. Postal 28 \\ 13001-970 Campinas, SP, Brazil \\ ${ }^{3}$ Laboratório de Separações Físicas, Departamento de Engenharia de Alimentos, \\ Universidade Estadual de Campinas, Cx. Postal 6121, 13083-970 Campinas, SP, Brazil
}

Manuscript received on September 24, 2001; accepted for publication on October 16, 2001; presented by OtTo R. GotTLieB

\begin{abstract}
Ocimum selloi Benth, a native plant of Brazil, has medicinal uses as anti-diarrheic, antispasmodic and antiinflammatory product. The yield of essential oils of the inflorescences, containing flowers and seeds, was $0.6 \%$, and the yield of leaves, collected in two different seasons, was $0.25 \%$ (June 2000) and 0.20\% (January 2001), respectively. The essential oils of the inflorescences and leaves presented as major constituents trans-anethol $(41.34 \%, 45.42 \%, 58.59 \%)$ and methyl chavicol $(27.10 \%, 24.14 \%, 29.96 \%)$.
\end{abstract}

Key words: medicinal plants, Ocimum selloi, essential oil, leaves, inflorescence.

\section{INTRODUCTION}

Brazil plays an important role as a country having megadiversity, with the highest vegetable genetic diversity of the world. It has more than 55,000 known species in an estimated total between 350,000 and 550,000 (Nodari and Guerra 1999), and many of them present biological activity.

The genus Oсітиm includes approximately 30 species, many of which are used by laymen as medicines, culinary herbs and for insect control. These species are rich in essential oils (Grayer et al. 1996).

Among the native plants of Brazil, in this genus and with medicinal use, we find Ocimum selloi Benth, an herbaceous annual plant of the family

Correspondence to: Marcia Ortiz Mayo Marques

E-mail:mortiz@cec.iac.br

*Communicated to XXII RESEM (2000).
Lamiaceae that is found in the Southeast and South Regions of Brazil (Schmidt 1858, cited by Martins 1998). It is popularly known as "paregoric elixir" in the states of Rio de Janeiro and Espírito Santo, as anise and "alfavaquinha" in Minas Gerais and "atroveran' in São Paulo. These popular terms refer to its pharmacological properties (for its use being similar to a medicine commercially known as paregoric elixir), to its chemical properties (anise, for its odor similarity to the fruits of Pimpinella anisum or Foeniculum vulgare, anise and fennel, respectively), and to its similarity with other species of the Ocimum genus (Martins 1998). It has been used as an anti-diarrheic, antispasmodic and anti-inflammatory product, as these properties have been observed in pre-clinical tests (Vanderline et al. 1994).

Martins (1998) performed the isoenzymatic characterization, morphological and the chemical 
composition analysis of the essential oils of both the inflorescences and the young stems with leaves of the Ocimun selloi, from two populations in the state of Minas Gerais, one being from the urban region of Viçosa (access A) and the other from Tiradentes (access B), subjected to the same conditions of cultivation. Accesses A and B presented different morphological, biochemical and essential oils composition.

The essential oil of access A presented methyl chavicol as its major component $(81.81 \%$ for inflorescences and $80.70 \%$ for stems with leaves) and access B presented methyl eugenol $(63.00 \%$ and $63.08 \%$, respectively), with no methyl chavicol in access B and small amounts of methyl eugenol in access A. In view of these results, the authors propose the occurrence of two taxonomical varieties for the species. The production of secondary metabolites results from complex interactions between biosynthesis, transport, stocking and degradation (Santos 1999). These processes, in turn, are governed by genes, being influenced by inheritance, physiological and climatic (temperature, seasonal effects, light intensity, day length) and edaphic factors (Santos 1999, Harborne 1977).

In order to contribute to the chemotaxonomy of the species, it was performed a study of the chemical composition of the essential oils of the inflorescences, containing flowers and seeds, and of the leaves of Ocimum selloi, collected in two different seasons and originated from Botucatu, State of São Paulo, Brazil.

\section{MATERIALS AND METHODS}

The vegetable material of this study comes from the medicinal plant germplasm collection of the Faculty of Agronomical Sciences of the Universidade Estadual Paulista in Botucatu, State of São Paulo, Brazil.

A sample of the inflorescences (flowers and seeds) and leaves from Ocimum selloi was collected in June 2000, from 08:00 to 09:00 AM, and the second sample of leaves was collected in January 2001, at the same hours.

The essential oils of the inflorescences and fresh leaves were extracted by hydrodistillation (Clevenger-type apparatus), using approximately $100 \mathrm{~g}$ of vegetable material for a period of three hours.

The analysis of the chemical composition of the essential oils was made using gas chromatography mass spectrometry, (GC-MS, Shimadzu, QP 5000); operating at $70 \mathrm{eV}$, equipped with capillary column of fused silica DB-5 ( $\mathrm{J} \&$ Wiley Scientific, $30 \mathrm{~m} \times$ $0.25 \mathrm{~mm} \times 0.25 \mu \mathrm{m})$, injector and detector at $240^{\circ} \mathrm{C}$ and $230^{\circ} \mathrm{C}$, helium as carrier gas $(1.7 \mathrm{~mL} / \mathrm{min})$ and the following temperature program: $50^{\circ} \mathrm{C}(5 \mathrm{~min})$ $-280^{\circ} \mathrm{C}, 5^{\circ} \mathrm{C} / \mathrm{min}$.

The retention index (RI) of the substances were obtained by co-injection of the essential oil with a standard mixture of hydrocarbons (C9-C40), using the Van den Dool and Kratz equation (Van den Dool and Kratz 1963).

The identification of the chemical constituents was effected by means of a comparative analysis of the mass spectrum of the substances with those of the database of the system GC-MS (Nist 62.lib) and the literature (McLafferty and Stauffer 1989) and retention index (Adams 1995).

\section{RESULTS}

The yield of the essential oil from inflorescences was higher $(0,6 \%)$ than the one obtained with the leaves of Ocimum selloi $(0.25 \%$ and $0.20 \%$, collected in June/2000 and January/2001).

As shown in Table I, the essential oils from the inflorescences and leaves presented as main components trans-anethol $(41.34 \% ; 45.42 \% ; 58.59 \%)$ and methyl chavicol $(27.10 \% ; 24.14 \% ; 29.96 \%)$.

\section{DISCUSSION}

The presence of trans-anethol as a major constituent in essential oils explains the odor similarity of this species as compared to anise (Pimpinella anisum), which presents aromatizing activity, and is stimulant of digestion and carminative (Sousa et al. 1991).

Besides the major constituents (trans-anethol and methyl chavicol), the inflorescences and the leaves presented cis-anethol as one of the most abun- 


\section{TABLE I}

Percentage composition of the essential oils from Ocimum selloi.

\begin{tabular}{l|c|c|c}
\hline \multirow{2}{*}{ Substance } & Inflorescences & \multicolumn{2}{|c}{ Leaves } \\
\cline { 2 - 4 } & & June 2000 & January 2001 \\
\hline 3-octenol & $\operatorname{tr}$ & 1.81 & 0.24 \\
trans-ocimene & - & 0.10 & $\operatorname{tr}$ \\
methyl chavicol & 27.10 & 24.14 & 29.96 \\
cis-anethol & 4.54 & 3.95 & 2.96 \\
trans- anethol & 41.34 & 45.42 & 58.59 \\
$\delta$-elemene & 0.14 & 0.19 & 0.04 \\
$\alpha$-copaene & 1.37 & 1.01 & 0.45 \\
$\beta$-bourbonene & 0.34 & 0.37 & 0.11 \\
$\beta$-cubebene & 0.22 & 0.15 & $\operatorname{tr}$ \\
$\beta$-elemene & 0.25 & 0.49 & 0.22 \\
methyl eugenol & 0.07 & 0.12 & 0.10 \\
trans-caryophyllene & 3.47 & 1.83 & 0.80 \\
$\beta$-gurjunene & $\operatorname{tr}$ & 0.06 & $\operatorname{tr}$ \\
$\alpha$-humulene & 0.18 & 0.17 & 0.05 \\
allo-aromadendrene & 0.23 & 0.18 & 0.04 \\
germacrene D & 1.81 & 4.21 & 0.94 \\
$\beta$-selinene & 3.34 & 4.14 & 0.93 \\
$\alpha$-(E,E)-farnesene & 0.75 & 1.08 & 0.44 \\
$\delta$-cadinene & 0.96 & 0.73 & 0.34 \\
\hline & $\operatorname{tr} \leq 0.03 \%$. & & \\
& &
\end{tabular}

dant components, ranging from $2.96 \%$ to $4.54 \%$.

Regarding the two different seasons when the leaves were harvested, it was observed a relative decrease of the chemical constituents, with the exception of methyl chavicol and trans-anethol.

Although the essential oils of inflorescences and leaves of Ocimum selloi originated from Botucatu/SP showed the presence of methyl chavicol and of methyl eugenol, the later in low relative proportion $(0.07 \%$ to $0.12 \%)$, these essential oils had a different chemical composition from the two populations from the State of Minas Gerais, because anethol was not observed in the two accesses previously related in the literature (Martins 1998). In view of these results, it is concluded that the plants collected in Botucatu/SP, constitute another chemotype of Ocimum selloi.

\section{ACKNOWLEDGMENTS}

The authors are grateful to Fundação de Amparo à Pesquisa do Estado de São Paulo (FAPESP) for financial support (1999/01962-1). Lilia A.S. Moraes also thanks the $\mathrm{PhD}$ assistantship provided by FAPESP (00/10053-4).

\section{RESUMO}

Ocimum selloi Benth, planta nativa do Brasil de uso medicinal, tem sido utilizada como antidiarréico, antiespasmódico e antiinflamatório. O rendimento dos óleos essenciais das inflorescências, contendo flores e sementes, foi de $0,6 \%$ e das folhas, coletadas em duas épocas do ano, foi de $0,25 \%$ (junho/00) e $0,20 \%$ (janeiro/01), respectivamente. Os óleos essenciais das inflorescências e folhas apresentaram como constituintes majoritários o trans- 
anethol $(41,34 \%, 45,42 \%, 58,59 \%)$ e methyl chavicol $(27,10 \%, 24,14 \%, 29,96 \%)$.

Palavras-chave: plantas medicinais, Ocimum selloi, óleo essencial, folhas, inflorescências.

\section{REFERENCES}

Adams RP. 1995. Identification of essential oil components by gas cromatography/mass spectroscopy. Allured Pub. Carol Stream, 468p.

Grayer RJ, Kite GC, Golsdstone FJ, Bryan Paton A AND Putievsky E. 1996. Infraspecific taxonomy and essential oil chemotypes in sweet basil, Ocimum basilicum. Phytochemistry 4: 1033-1039.

Harborne JB. 1977. The plant and its biochemical adaptation to the environment. In: INTRODUCTION to Ecological Biochemistry, London: Academic Press, p. 1-27.

Martins ER. 1998. Estudos em Ocimum selloi Benth: Isoenzimas, morfologia e óleo essencial. In: MiNG LC ET AL., Plantas medicinais, aromáticas e condimentares: avanços na pesquisa agronômica, Botucatu: UNESP, p. 97-126.

McLafferty FW and Stauffer DB. 1989. The Wiley/NBS registry of mass spectral data, New York: John Wiley Sons, Vol I-II.
NodARi RO AND GuerRa MP. 1999. Biodiversidade: Aspectos Biológicos, Geográficos, Legais e Éticos. In: Simões ET AL. (Ed.). Farmacognosia: da planta ao medicamento, Porto Alegre/ Florianópolis: Ed. Universidade/ UFRGS/ Ed. da UFSC, p.11-24.

SANTos RI. 1999. Metabolismo básico e origem dos metabólitos secundários. In: SimõEs et AL. (Ed.). Farmacognosia: da planta ao medicamento, Porto Alegre/ Florianópolis: Ed. Universidade/ UFRGS/ Ed. da UFSC, p. 323-354.

Sousa MP, Matos MEO, Matos FJA, Machado MIL and Craveiro AA. 1991. Constituintes Químicos Ativos de Plantas Medicinais Brasileiras, Edições UFC/ Laboratório de Produtos Naturais, Fortaleza, $414 \mathrm{p}$.

Van Den Dool H and Kratz DJ. 1963. A generalization of the retention index system including liner temperature programmed gas-liquid partition chromatography. J Chromatography 11: 463-467.

VANDERline FA, Costa EA AND D'Angelo LCA. 1994. Atividades farmacológicas gerais e atividade antiespasmódica do extrato etanólico de Ocimum selloi Benth, (elixir paregórico). Simpósio de Plantas Medicinais do Brasil, Fortaleza, Brazil, Proceedings... Fortaleza: UFC. 